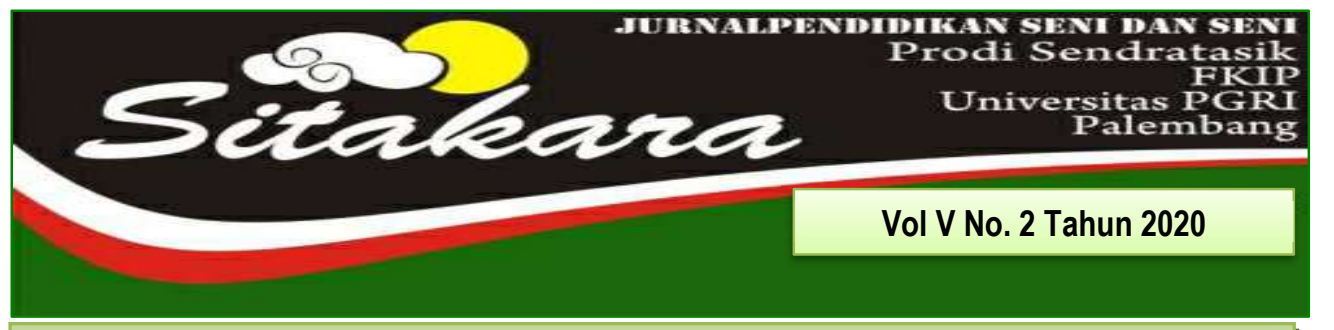

FUNGSI DAN MAKNA BHAJAN PADA UPACARA AGAMA HINDU DI KUIL SHRI MARIAMMAN KOTA MEDAN

(Agung Suharyanto, dkk)

KESENIAN SRANDUL DALAM UPACARA BERSIH DESA BULU KALURAHAN KARANGMOJO KECAMATAN KARANGMOJO KABUPATEN GUNUNGKIDUL YOGYAKARTA

(Supriyanto)

FUNGSI DAN MAKNA LAGU GUBANG DALAM UPACARA SIAR MAMBANG PADA MASYARAKAT TANJUNGBALAI

(Theo henry tua siagian ${ }^{1}$, pulumun p. Ginting ${ }^{2} \&$ wiflihani)

FUNGSI TARI MAPAK ADAT MUARA KUANG SEBAGAI TARI SAMBUT

(Nadia Rahma Aprilia', Dessy Wardiah², Treny Hera ${ }^{3}$ )

MAKNA SIMBOLIK RAGAM HIAS PADA RUMAH LIMAS PALEMBANG

(Ferri Hidayad ${ }^{1}$ Decky Kunian ${ }^{2}$ )

GAYA MUSIK SAHILIN DALAM KESENIAN MUSIK BATANGHARI SEMBILAN DI KOTA PALEMBANG

(Feri Firmansyah)

TRANSPOSISI TTI (TRANSFER, TRANSLATION, IMITATE) DALAM PEMBELAJARAN NOTASI MUSIK MELALUI SCORE CREATOR

(A Heryanto ${ }^{1}$ Dedy Firmansyah ${ }^{2}$ )

RASE TAK SERUPE MUSIK MELAYU TRADISI DENGAN PENGEMBANGAN MUSIK MODERN DALAM RUANG PERTUNJUKAN KOMPOSISI MUSIK NUSANTARA (Rio Eka Putra)

BENTUK SYAIR LAGU DALAM PERTUNJUKAN SYAROFAL ANAM DI PEDESTRIAN S UDIRMAN KOTA PALEMBANG

(Nofroza Yelli ${ }^{1}$ Deria Sepdwiko² ${ }^{2}$

"Betenun" Sebuah Wujud Proses Kreatif Mahasiswa Seni Pertunjukan Universitas PGRI PALEMBANG

(Nurdin $^{1}$ Naomi Diah Budi Setyaningrum ${ }^{2}$ ) 
DAFTAR ISI

FUNGSI DAN MAKNA BHAJAN PADA UPACARA AGAMA HINDU DI KUIL 1-15 SHRI MARIAMMAN KOTA MEDAN

(Agung Suharyanto, dkk)

KESENIAN SRANDUL DALAM UPACARA BERSIH DESA BULU KALURAHAN

$16-26$

KARANGMOJO KECAMATAN KARANGMOJO KABUPATEN GUNUNGKIDUL YOGYAKARTA

(Supriyanto)

FUNGSI DAN MAKNA LAGU GUBANG DALAM UPACARA SIAR MAMBANG 27-39 PADA MASYARAKAT TANJUNGBALAI

(Theo henry tua siagian ${ }^{1}$, pulumun $p$. Ginting ${ }^{2} \&$ wiflihani)

FUNGSI TARI MAPAK ADAT MUARA KUANG SEBAGAI TARI SAMBUT

40-52

(Nadia Rahma Aprilia', Dessy Wardiah², Treny Hera')

MAKNA SIMBOLIK RAGAM HIAS PADA RUMAH LIMAS PALEMBANG

53-61

(Ferri Hidayad ${ }^{1}$ Decky Kunian ${ }^{2}$ )

GAYA MUSIK SAHILIN DALAM KESENIAN MUSIK BATANGHARI SEMBILAN DI $\quad 62-76$ KOTA PALEMBANG

(Feri Firmansyah)

TRANSPOSISI TTI (TRANSFER, TRANSLATION, IMITATE) DALAM 77-85 PEMBELAJARAN NOTASI MUSIK MELALUI SCORE CREATOR (A Heryanto ${ }^{1}$ Dedy Firmansyah ${ }^{2}$ )

RASE TAK SERUPE MUSIK MELAYU TRADISI DENGAN PENGEMBANGAN MUSIK MODERN DALAM RUANG PERTUNJUKAN KOMPOSISI MUSIK NUSANTARA

(Rio Eka Putra)

BENTUK SYAIR LAGU DALAM PERTUNJUKAN SYAROFAL ANAM DI PEDESTRIAN SUDIRMAN KOTA PALEMBANG

(Nofroza Yelli ${ }^{1}$ Deria Sepdwiko ${ }^{2}$ )

"BETENUN" SEBUAH WUJUD PROSES KREATIF MAHASISWA SENI

$109-120$ PERTUNJUKAN UNIVERSITAS PGRI PALEMBANG

(Nurdin ${ }^{1}$ Naomi Diah Budi Setyaningrum ${ }^{2}$ )

86-95 


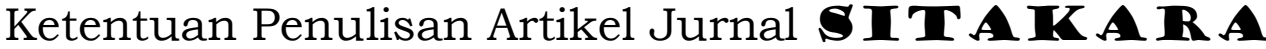

1. Naskah berbahasa Indonesia bertemakan Seni Budaya yang meliputi hasil penelitian pengajaran seni budaya, cabang seni, dan kebudayaan.

2. Naskah harus asli dan belum pernah dimuat dalam media lain. Naskah dapat berupa hasil penelitian perorangan atau kelompok.

3. Naskah ditulis dengan cara-cara yang sesuai dengan ketentuan penulisan artikel ilmiah menggunakan bahasa Indonesia yang baku, berupa ketikan, beserta soft line dalam CD-RW atau dengan mengirimkan email pada redaksi Jurnal SITAKA RA dengan alamat email: jurnalsitakarasendratasik@yahoo.com, spasi 1,5 jenis huruf Arrial Narrow ukuran 12, dengan panjang naskah antara 8-15 halaman pada kertas A4.

4. Artikel hasil penelitian memuat:

JUDUL

Nama Penulis

Abstrak

A. PENDAhuluan

B. METODE PENELITIAN

C. HASIL DAN PEMBAHASAN

D. SIMPULAN

5. Artikel kajian konseptual memuat:

JUDUL

Nama Penulis

Abstrak

PENDAHULUAN
: XXX (HURUF KAPITAL)

: (disertai jabatan dan institusi)

: (Bahasa Indonesia yang memuat 100150 kata diikuti kata kunci, dengan jenis huruf Arrial Narrow dan ukuran huruf 11 spasi tunggal serta dicetak miring)

: (Memuat latar belakang masalah, tinjauan pustaka secara ringkas, masalah penelitian dan tujuan penelitian)

: (Berisi simpulan)

\section{: XXX (HURUF KAPITAL)}

: (disertai jabatan dan institusi)

: (Bahasa Indonesia yang memuat 100150 kata diikuti kata kunci, dengan jenis huruf Arrial Narrow dan ukuran huruf 11 serta dicetak miring)

: (Memuat latar belakang masalah, tinjauan pustaka secara ringkas, 
Sub Judul

Sub Judul

SIMPULAN

DAFTAR PUSTAKA masalah penelitian dan tujuan

penelitian)

: Sesuai dengan kebutuhan (tanpa

numbering)

: (Berisi simpulan dan saran)

: (Berisi pustaka yang dirujuk dalam uraian naskah

6. Referensi sumber dalam teks artikel ditulis dengan menggunakan side note, contoh: (Jalalluddin, 1991:79); (Taufik, 2005;350); (Hamid dan Madjid, 2011:43). Sementara penulisan daftar pustaka disusun dengan ketentuan. Nama Pengarang. Tahun Terbit. Judul (dicetak miring). Kota Terbit: Nama Penerbit. Contoh: Koentjaraningrat. 2010. Manusia dan Kebudayaan Di Indonesia. Jakarta: Djambatan.

Daftar pustaka hanya memuat pustaka/sumber yang dirujuk dalam uraian dan disusun menurut abjad, tanpa nomor urut.

7. Naskah yang dimuat akan disunting kembali oleh redaksi tanpa mengubah isinya.

8. Naskah yang ditolak (tidak bisa dimuat) akan dikirim kembali ke penulis dengan pemberitahuan tertulis dari redaksi atau alamat email.

9. Penulis yang naskahnya dimuat akan mendapatkan 1 (satu) majalah nomor yang bersangkutan.

10. Contact Person: Treny Hera (085357344704) dan Mainur (081373165553). 


\title{
RASE TAK SERUPE MUSIK MELAYU TRADISI DENGAN PENGEMBANGAN MUSIK MODERN DALAM RUANG PERTUNJUKAN KOMPOSISI MUSIK NUSANTARA
}

\author{
Oleh: \\ Rio Eka Putra \\ (FKIP Universitas PGRI Palembang) \\ Email: ryoep@yahoo.com
}

\begin{abstract}
ABSTRAK
Penelitian yang berjudul Rase Tak Serupe musik Melayu tradisi dengan pengembangan musik modern dalam ruang pertunjukan komposisi musik Nusantara". Dilatarbelakangi oleh tiga tujuan adalah: 1) Untuk menciptakan dan menumbuh-kembangkan sebuah 'genre musik baru' yang bersumber dari musik Zapin Melayu Riau. 2) Menciptakan sebuah karya komposisi musik baru mengutamakan kekuatan perbedaan rasa dalam improvisasi laram menyangkut karakteristik pembawaan melodi. 3) Dapat menyajikan atau menampilkan sebuah karya musik vokal dengan aransemen dan instrumen dengan suasana baru. Melalui metode pendekatan Modern sebuah karya komposisi musik dapat dihadirkan dengan pengembangan garap dengan teknik-teknik terminolgi musik, dengan upaya-upaya mengembangkan yang berangkat dari musik aslinya tampa menghilangkan ciri khas musik aslinya. Hasil penelitian menunjukkan bahwa dengan menggunakan metode pendekatan tradisional dapat disimpulkan bahwa musik tradisi dapat diolah ke dalam bentuk apapun tampa menghilangkan ciri khas aslinya, dengan pemilihan materi dari tradisi tersebut dapat mempertahankan sebuah tradisi tampa menghilangkan ciri khas atau bentuk aslinya. Dengan hasil sebuah pertunjukan karya yang berdurasi lebih kurang 20 menit yang terdiri dari 3 karya berdurasi 7 menit. Pertunjukan karya baru ini berlansung dengan baik karena peneliti mampu memberikan sebuah pertunjukan komposisi musik dengan hasil yang memuaskan dan mampu memotivasi dari berbagai pihak, baik dari seniman tradisi itu sendiri ataupun mahasiswa khususnya sendratasik.
\end{abstract}

Kata Kunci: Musik Melayu Tradisional, Pengembangan musik Modren, Ruang pertunjukan Musik Nusantara

\section{A.PENDAHULUAN}

Musik Zapin adalah salah satu genre musik yang terdapat di Melayu Riau, dimana musik Zapin terkait dengan keberadaan pedagang-pedagang dari bangsa Arab yang menyebarkan agama Islam ke Indonesia, yang umumnya dilakukan melalui pendekatan kesenian.

Fungsi utama musik Zapin adalah pengiring tari Zapin, karena musik dan tari memang erat sekali hubungannya satu sama lain. Terdapat tari yang diringi oleh musik internal dan ada juga tari yang diiringi dengan musik eksternal. Musik 
internal dalam tari yaitu musik iringan tari yang dihasilkan oleh para pemainnya sendiri, sedangkan iringan eksternal dilakukan oleh orang lain yang datang dari luar tubuh penari sendiri. Marwas dan petikan gambus Melayu yang dibawakan, mengikuti motif atau pola gerak Zapin, pada dasar bisa dikatakan iringan eksternal pada tarian Zapin (Zulkifli, 1998:2).

Fungsi musik dalam tarian ini sebagai pemberi iringan, menstabilkan pergerakan, mempertegas aksentuasi gerak langkah supaya keutuhan penyajian tari Zapin ini menjadi lebih sempurna. Syair-syair lagu yang mengiringi tarian Zapin adalah bertema ucapan salam dan maaf. Sedangkan alat musik yang digunakan dalam ansambel musik Zapin versi tari Zapin Siak Indrapura adalah; satu buah gambus Melayu dan lima buah marwas. Biasanya setiap lagu pada musik Melayu selalu dibangun dalam tiga bagian melodi, yaitu: bagian awal, bagian tengah dan bagian akhir. Dalam konteks komposisi musik Zapin, bagian awal berfungsi sebagai pembuka lagu (laram), bagian tengah berfungsi sebagai batang lagu "nyanyian" dan bagian akhir sebagai penutup lagu (Waynab).

Dengan demikian, struktur penyajian lagu dalam musik Zapin Riau, terdapat tiga bagian yaitu introduksi (laram), nyanyian, dan akhir (waynab). Bagian introduksi yang disebut laram adalah sebuah istilah lokal dari produk budaya musikal kebudayaan Melayu pada umumnya. Laram bisa dimaknai sebagai awal lagu dan sekaligus berfungsi sebagai bagian introduksi (pembuka lagu), digunakan sebagai pembuka pertunjukan musik dan tari Zapin. Ciri-cirinya adalah:

a. Melodi awal sebelum masuknya lagu Zapin bersifat free rhythm (ritme bebas).

b. Mempunyai aksentuasi pada bagian melodi tertentu.

C. Jeda-jeda melodi pada bagian phrase dan motif yang disertai dengan penggunaan teknik permainan picking (teknik permainan alat musik berdawai yang menggunakan pick), yang membentuk ritme.

d. Pergerakan melodi yang rapat pada ritme bebas (free rhythm) di 
setiap lagu yang berirama Zapin Melayu.

Bagian kedua atau bagian tengah disebut "nyanyian" lagu pokok. Secara umum istilah 'lagu' dalam kebudayaan musikal Melayu disebut juga dengan 'nyanyian'. Namun dalam konteks musik tari Zapin, nyanyian menjadi struktur bagian tengah musik iringan tari tersebut dan berposisi sebagai 'batang' dalam musik tari. Sebelum masuknya melodi nyanyian Zapin, selalu ditandai dengan permainan melodi laram untuk masuknya gendang dan Marwas, yang merupakan bagian dari batang lagu. Nyanyian Zapin ini dimainkan atau dinyanyikan dalam durasi tertentu, Sesuai dengan kebutuhan komposisi musik Zapin atau musik iringan Zapin.

Ketiga, Bagian akhir yang disebut waynab. Waynab adalah istilah dalam musik Zapin Melayu yang secara umum berfungsi untuk mengakhiri sebuah lagu Zapin. Waynab dalam konteks pertunjukan musik Zapin digunakan untuk menutup sebuah lagu maupun sebuah tarian (terdapat pada bagian akhir lagu). Karakter melodi waynab tidak sekompleks melodi laram, dan tidak terlalu banyak menggunakan variasi melodi, melainkan menggunakan melodi tertentu untuk menutup sebuah nyanyian musik Zapin. Persamaan waynab dengan laram adalah adanya, melodi yang juga bersifat free rhythm (Nedy Winuza Dkk., Wawancara di Padangpanjang, 10-2-2012).

Berdasarkan analisis ketiga bagian dari bentuk lagu Zapin, penulis tertarik mengembangkan musik tradisi melayu tersebut ke bentuk modern, sehingga dengan tidak menghilangkan cirri khas aslinya. Bentuk tersebut akan dikemas dengan sedemikian rupa sehingga dapat menjadi acuan atau apresiasi kepada mahasiswa khususnya Universitas PGRI Palembang.

Berdasarkan pengamatan dan analisis terhadap musik tradisional melayu maka dapat dirumuskan ke dalam pertanyaan yaitu: "bagaimana menciptakan sebuah bentuk komposisi musik baru yang berangkat dari musik Melayu tradisi dengan pengembangan musik modern dalam ruang pertunjukan komposisi musik Nusantara" adapun penelitian ini bertujuan untuk menciptakan dan menumbuhkembangkan sebuah 'genre musik baru' yang bersumber dari musik Zapin Melayu 
Riau. menciptakan sebuah komposisi musik baru yang berangkat dari musik Melayu tradisi dengan pengembangan musik modern dalam ruang pertunjukan komposisi musik Nusantara". Memberikan pemahaman kepada masyarakat Melayu Riau tentang kekayaan budayanya sehingga menimbulkan rasa mencintai budaya milik sendiri. Serta menambah referensi bagi mahasiswa dalam proses penggarapan karya dalam mata kuliah komposisi musik di Prodi Sendratasik.

Peneliti berharap penelitian ini dapat memberikan manfaat yang berarti bagi pihak-pihak yang bersangkutan, di antaranya :

1. Bagi Universitas dapat meningkatkan kualitas pembelajaran Komposisi musik bagi mahasiswa Universitas PGRI Palembang Khususnya Prodi Sendratasik.

2 Bagi Dosen dapat membantu upaya dosen lain dalam meningkatkan kreativitas dalam pembelajaran mata kuliah komposisi musik.

3 Bagi mahasiswa dapat meningkatkan kreativitas mahasiswa dalam pengarapan komposisi musik nantinya.

Judul karya Rase Tak Serupe mengandung pengertian bahwa dalam setiap pelahiran dari permainan melodi instrumen melayu mempunyai rasa yang sama, tetapi dapat di bentuk dan diciptakan oleh masing-masing pemain instrumennya dalam ragam dan teknik yang berbeda. Selain itu, komposisi musik Rase Tak Serupe juga dimaknai sebagai interpretasi pengkarya terhadap 'teknik permainan alat musik' bahwa setiap pemain melakukan improvisasi yang sama dasarnya, namun dalam pelahirannya berbeda-beda.

\section{Musik Melayu Tradisi}

Menurut sedyawati (1992 : 23) pengertian lagu daerah/tradisional adalah musik yang digunakan sebagai perwujudan dan nilai budaya yang sesuai dengan tradisi, seni budaya yang sejak lama turun menurun dari satu generasi ke generasi selanjutnya, dan musik daerah hidup dan berkembang pada daerah tertentu. Sedangkan musik melayu adalah musik yang berkembang di berbagai wilayah seperti Malaysia, Aceh, Medan, Riau dan 
lain-lain. Ciri dari musik melayu ini mencakup Musik melayu dalam bentuk Langgam atau Senandung, Musik Joget, Musik Zapin, Musik Silat, Musik Inang, Musik Ghazal.

Menurut Tjokorde Raka Sukawati (2003) mengatakan bahwa karya yang berkualitas ditentukan oleh tiga faktor yaitu: kreatifitas, bakat dan Teksu. Kreativitas adalah suatu kemampuan untuk menyusun dan merubah suaatu gagasan abstrak menjadi suatu ciptaan yang realis, asli dan tak ada duanya. Kreativitas harus dapat memperbaiki, memperindah dan lebih mengefesienkan gagasan sebelumya. Ada enam cirri orang kreatif adalah: kepekaan akan masalah, orisinalitas, keluesan pikiran, kefasihan akan gagasan, imaginasi dan ingin tahu.

Musik modern menurut David Ewen adalah ilmu pengetahuan tentang kombinasi ritmik dari nada-nada, baik vocal maupun instrumental, yang meliputi melodi sebagai ekspresi dari segala sesuatu yang ingin diungkapkan terutama aspek emosional.

\section{Komposisi Musik}




\section{Sintetis}

Idiom-idiom yang terdapat dalam karya ini, dengan memakai pola tabuhan dari musik melayu itu sendiri idiom yang lain seperti: Alat musik string: Gambus, Acordion, Piano, Cello, Biola, Contrabass, Alat musik percusion: darabuka, gendang Melayu, Doll. Serta memakai vokal-vokal.

\section{Elaborasi}

Elaborasi digunakan untuk
memperkuat gagasan yang telah
dibangun, dengan tidak menghilangkan ciri
khas tradisi dari musik melayu akan tetapi
garapan musik modern lebih ditonjolkan.

\section{Realisasi}

Dalam komposisi ini yang terdiri dari tiga bagian, masing-masing dari bagian ini tidak lepas dari ketukan rentak Zapin. Pada bagian awal mentitik beratkan pada permainan free rhythm gambus, dengan penghadiran melodi free rhythm Gambus dengan memakai accord sebagai alas, serta unisono-unisono yang akan dihadirkan pada string. Pada bagian dua berangkat dari permainan improvisasi Laram pada gambus yaitu diambil dari salah satu pola ritme permainan gambus dan mengembangkan jadi satu phrase melodi, dengan memakai rentak Zapin matrik $7 / 8$ pada bagian ke tiga melodi pengembangan dari melodi improvisasi yang tema komposisi ini dengan memakai modulasi chord dan dikembangkan.

\section{Penyelesaian}

Setelah bagian dari komposisi ini mulai terbentuk barulah pengkarya memberi variasi-variasi yang sesuai dengan komposisi ini, supaya komposisi ini lebih terlihat tergarap. Dalam tahap ini merupakan tahap finishing dalam karya ini, pengkarya melakukan latihan, pada latihan tersebut dilakukan latihan 'perbagian' satu persatu, latihan dilakukan berulang-ulang agar per-bagian pada karya dapat dimainkan dengan baik.

\section{B. METODE PENELITIAN}

Metode penelitian ini ialah penelitian kualitatif guna mencari sebuah ciri, unsur, sifat mengenai suatu fenomena yang diawali dengan mengumpulkan, menganalisis dan mengintrepretasikan data. Dalam penelitian ini, peneliti menggunakan tiga karakteristik penelitian kualitatif guna memaksimalkan hasil penelitian yang dilakukan yaitu (1) Latar belakang ilmiah sebagai instrument penelitian guna mendapatkan data yang kongkrit. Dalam hal ini penulis melakukan 
pengamatan, serta pencermatan data secara langsung melalui medium pedoman wawancara dan hasil wawancara yang elah diajukan kepada para responden. (2) Manusia sebagai alat (instrumen) penelitian ialah sebuah proses yang umum digunakan dalam beberapa penelitian, dalam penelitian ini penulis juga melakukan hal yang sama yaitu melakukan wawancara yang berdasar dari pedoman wawancara yang telah dibuat untuk mendapatkan data secara verbal yang kemudian akan dilakukan pengolahanpengolahan tertentu untuk menjadikannya ilmiah. (3) Deskriptif menjadi instrumen yang dipilih oleh peneliti merupakan sebuah tindakan yang bertujuan untuk mencari sebuah ciri, unsur, sifat mengenai suatu fenomena yang diawali dengan mengumpulkan, menganalisis dan mengintrepretasikan data. Dalam penelitian ini, peneliti mengupas dan menguraikan proses penciptaan karya musik Rase Tak Serupe karya peneliti sendiri.

\section{HASIL PENELITIAN DAN \\ PEMBAHASAN}

\subsection{Hasil Penelitian}

Pada bab ini akan dilaporkan hasil penelitian dan pembahasan mengenai Rase Tak Serupe musik Melayu tradisi dengan pengembangan musik modern dalam ruang pertunjukan komposisi musik Nusantara, yang terdiri dari : (1) Gambaran Umum; (2) Pengembangan bentuk tradisi ke bentuk modern dalam ruang komposisi musik Nusantara (3) Kendala pengembangan Pengembangan bentuk tradisi ke bentuk modern dalam ruang komposisi musik Nusantara.

Pengembangan bentuk tradisi ke bentuk modern dalam ruang komposisi musik Nusantara

Bentuk komposisi musik ini memakai pendekatan modern, pendekatan modern adalah: upaya memformulasikan kembali idiom-idiom tradisi ke dalam bentuk baru. Dengan mengolah idiom tradisi seperti tabuhan yang dikemas kedalam wujud yang memiliki makna kebaharuan (supanggah : 295).

\section{Kendala Pengembangan bentuk tradisi ke bentuk modern dalam}


ruang lingkup komposisi musik Nusantara.

Kendala-kendala atau faktor yang menghambat dalam proses pengembangan bentuk tradisi ke bentuk modern dalam ruang lingkup komposisi musik Nusantara meliputi berbagai hal yakni: Bagi peneliti, Kurang nya fasilitas pendukung seperti media alat musik, tempat latihan dan jadwal latihan terkesan molor dan tidak tepat waktu. Selain itu setiap pendukung karya memiliki kemampuan yang berbeda-beda dalam memainkan materi yang diberikan, hal ini juga yang memberikan tantangan tersendiri bagi peneliti untuk lebih mengenal karakter para pendukung dalam menyajikan materi dan metode pembeerian materi menjadi bervariasi.

\section{HASIL PENELITIAN DAN PEMBAHASAN}

\section{Konsep Pergelaran}

Panitia Pelaksana

Pimpinan produksi : (HMJ) Karawitan

Stage Manager: Beny Chandra

Komposer: Rio Eka Putra

Pendukung karya

Rio Eka Putra : Gambus

Hamzaini : Accordeon
Lidia Triani : Treangle / Vocal

Mailisa geovani : Marcas / Vocal

Beny Chandra : Marwas / Vocal

Erwind: Marwas / Vocal

Chandra putra : Mandolin

Romi : Biola

Ireng Maulana : Cello

Wirawan Nofrianto : Contrabass

Wahyu Kurniawan : Darabuka

Hendry kot : Gendang Melayu

Frindo Madeka: Doll Bengkulu

Sound Engineer: Jhori Andela, S. Sn.

Lighting / Artistic

Dedi Darmadi, S. Sn.

Penata kostum : Afrizal dkk.

Dokumentasi / foto: Rayhan Redha

\section{Deskripsi Lokasi dan Pentas}

Gedung pertunjukan Hoerijah

Adam ISI Padangpanjang merupakan suatu tempat pertunjukan karya ini karena selain Fasilitasnya yang memadai dan letaknya strategis, selain itu gedung ini juga memiliki pengaruh akustik ruangan yang sangat baik untuk sebuah pertunjukan musik.

\section{Durasi Waktu}

Durasi waktu dalam komposisi ini berkisar 20 menit. Keseluruhan waktu dimulai dari karya-karya mahasiswa yang 
lain seluruhnya sekitar 2 jam di mulai dari jam 20.00 Wib/Selesai.

\section{Susunan Acara}

a) Kata sambutan dan Ucapan selamat datang dari (MC).

b) Pertunjukan komposisi karya Rio Eka Putra Rase Tak Serupe

c) Pertunjukan komposisi karya Hamzaini "Kompangku"

d) Pertunjukan komposisi karya Rahmadina SM "Imbauan Pelayaran " bertempat di Auditorium Hoerijah Adam.

e) Pertunjukan komposisi karya Jumaidil Firdaus "Perkawinan tak Sejenis " bertempat di Auditorium Hoerijah Adam.

f) Penutup dan Ucapan selamat dari MC.

\section{Jadwal Pelaksanaan}

Pertunjukan ini dilaksanakan di Gedung Pertujukan Hoerijah Adam pada tanggal Selasa 24 Juli 2012 pertunjukan dimulai pada pukul 21.00 WIB.

\section{Bentuk Pertunjukan}

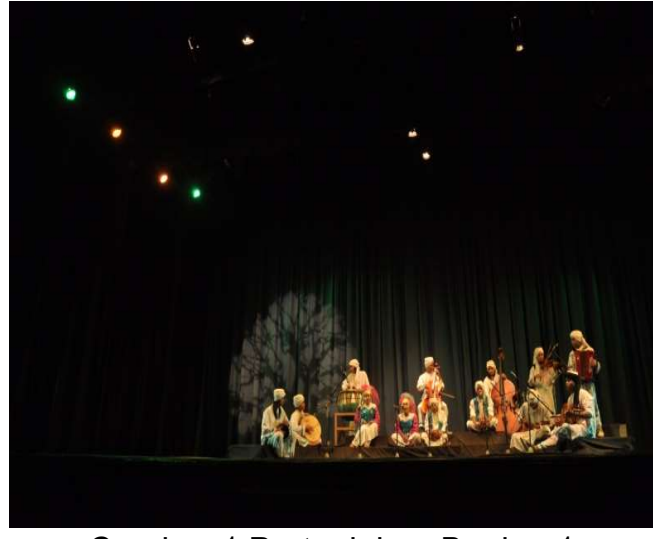

Gambar 1 Pertunjukan Bagian 1 ( foto : Rayhan Redha febrian Selasa 24 Juli 2012 )

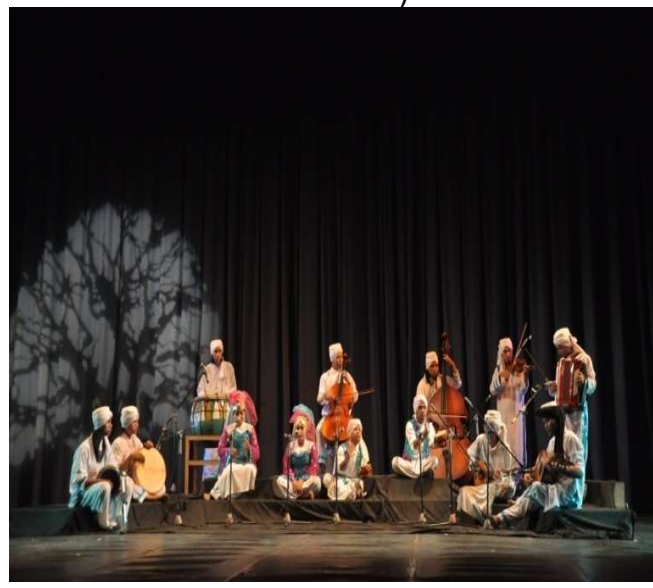

Gambar 2 Pertunjukan Bagian 2 ( foto : Rayhan Redha febrian Selasa 24 Juli 2012 )

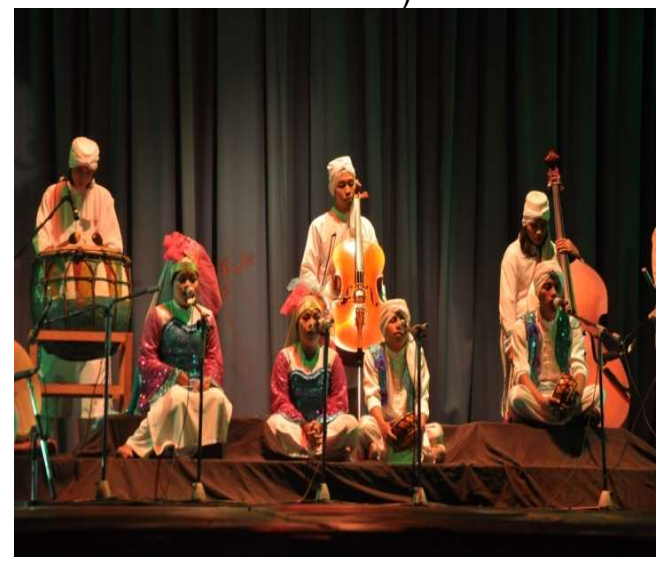

Gambar 3 Pertunjukan Bagian 3 
( foto : Rayhan Redha febrian Selasa 24 Juli 2012)

\section{SIMPULAN}

Berdasarkan pengarapan komposisi musik Rase Tak Serupe yang telah disajikan, setelah dianalisis kesenian musik Zapin merupakan sebuah kesenian tradisi yang kaya akan pengggarapan dan pengembangan dimana pada karya Rase Tak Serupe lebih pengarapan kepada formula dari laram sebuah ketertarikan yang menjadi ide dasar bagi pengkarya dengan mengembangkan formula yang terdapat pada laram dalam permainan gambus, untuk digarap ke dalam sebuah komposisi yang pendekatan garap interpretasi tradisi.

Dalam pengarapan komposisi ini, ternyata tidak semudah yang dibayangkan, butuh kesabaran, pemikiran yang matang, konsep dan ide dasar, pemilihan instrumen, pemilihan pendukung karya dan proses yang merupakan hal yang sangat penting dalam pembuatan komposisi musik. Setelah adanya karya ini, pengkarya berharap adanya rangsangan untuk mahasiswa dan para seniman untuk berkarya yang lebih menarik yang dapat mengakat citra musik tradisonal.

\section{DAFTAR PUSTAKA}

Sedyawati, (1992 : 23). "Lagu Daerah". Bandung. CV. Alfabeta.

Sukawati Tjokorde Raka (2003) dalam Pande Made Sukerta "Metode Penyusunan Karya Musik" ISI Press Solo. 2011.

Supanggah Rahayu. 1996.Komposisi (Baru) Karawitan" Makalah Disajikan Dalam Seminar Komposisi Musik Di Institut Seni Indonesia (Isi) Yogyakarta, Pada Bulan April

Zulkifli, "Zapin Asli Siak Sri Indrapura”, Makalah Seminar Zapin Nusantara. Yayasan Warisan Johor 1998.

Https://gjb3112yeni.woedpress.com./musik-Indonesia-/musik/modern. 